\title{
Age- and sex-related changes of the volume of maxillary sinuses quantified via cone
}

\section{beam computed tomography}

\author{
Alterações relacionadas à idade e sexo do volume de seios maxilares quantificadas através da \\ tomografia computadorizada de feixe de cônico \\ Cambios relacionados con la edad y el sexo del volumen de los senos maxilares cuantificados en \\ tomografía computarizada de haz cónico
}

Received: 10/24/2021 | Reviewed: 10/30/2021 | Accept: 11/01/2021| Published: 11/02/2021

\author{
Lucas Eigi Borges Tanaka \\ ORCID: https://orcid.org/0000-0002-7629-3191 \\ Universidade Estadual Paulista, Brazil \\ E-mail: lucaseigitanaka@gmail.com \\ Ademir Franco \\ ORCID: https://orcid.org/0000-0002-1417-2781 \\ Faculdade São Leopoldo Mandic, Brazil \\ Sechenov University, Russia \\ University of Dundee, United Kingdom \\ E-mail: franco.gat@gmail.com \\ Rafael Ferreira Abib \\ ORCID: https://orcid.org/0000-0003-1161-7834 \\ Faculdade São Leopoldo Mandic, Brazil \\ E-mail: rafaelferreiraabib@gmail.com \\ Luiz Roberto Coutinho Manhães Junior \\ ORCID: https://orcid.org/0000-0003-1642-5241 \\ Universidade Estadual Paulista, Brazil \\ Faculdade São Leopoldo Mandic, Brazil \\ E-mail:1rmradio@yahoo.com.br \\ Sergio Lúcio Pereira de Castro Lopes \\ ORCID: https://orcid.org/0000-0002-0882-5862 \\ Universidade Estadual Paulista, Brazil \\ E-mail: sergio.lopes@ fosjc.unesp.br
}

\begin{abstract}
Anatomical studies found in cone beam computed tomography (CBCT) an optimal resource for the three-dimensional (3D) assessment of the head and neck. When it comes to the maxillary sinuses, CBCT enables a life-size reliable volumetric analysis. This study aimed to assess the age and sex-related changes of the maxillary sinuses using volumetric CBCT analysis. The sample consisted of CBCT scans of 112 male $(n=57)$ and female $(n=55)$ individuals (224 maxillary sinuses) distributed in 5 age categories: $20\lceil-30,31-40,41-50,51 \mid 60$ and > 60 years. Image acquisition was accomplished with the i-CAT Next Generation device set with voxel size of $0.25 \mathrm{~mm}$ and field of view that included the maxillary sinuses (retrospective sample collection from an existing database). Image segmentation was performed in itk-SNAP (www.itksnap.org) software. The volume (mm3) of the segmented sinuses was quantified and compared pairwise based on side (left and right), sex (male and female) and age (five groups). Differences between left and right sides volume were not statistically significant $(\mathrm{p}>0.05)$. The mean volume of maxillary sinuses in males was $22 \%$ higher than females $(p=0.0001)$. Volumetric differences were not statistically significant between age categories for males and females $(\mathrm{p}>0.05)$. The discriminant power of sinuses' volume may support customized and patient-specific treatment planning based on sex.
\end{abstract}

Keywords: Anatomy; Cone beam computed tomography; Forensic dentistry; Maxillary sinus; Volume.

\section{Resumo}

Estudos anatômicos encontram na tomografia computadorizada do feixe de cone (TCFC) um recurso ideal para a avaliação tridimensional (3D) da cabeça e pescoço. Quanto aos seios maxilares, o TCFC permite uma análise volumétrica em tamanho real. Este estudo teve como objetivo avaliar as alterações relacionadas à idade e ao sexo dos seios maxilares por meio da análise volumétrica em TCFC. A amostra consistiu em tomografias de 112 indivíduos masculinos $(\mathrm{n}=57)$ e femininos $(\mathrm{n}=55)(224$ seios maxilares $)$ distribuídos em 5 categorias etárias: $20|-30,31|$ $40,41|-50,51|-60$ e > 60 anos. A aquisição de imagens foi realizada com o dispositivo i-CAT Next Generation com tamanho de voxel de $0,25 \mathrm{~mm}$ e campo de visão que incluía os seios maxilares (coleta retrospectiva de amostras 
de um banco de dados existente). A segmentação de imagens foi realizada no software itk-SNAP (www.itksnap.org). O volume (mm3) dos seios segmentados foi quantificado e comparado com base no lado (esquerda e direita), sexo (masculino e feminino) e idade (cinco grupos). As diferenças entre o volume dos lados esquerdo e direito não foram estatisticamente significativas $(\mathrm{p}>0,05)$. O volume médio de seios maxilares no sexo masculino foi $22 \%$ maior do que o feminino $(\mathrm{p}=0,0001)$. As diferenças volumosas não foram estatisticamente significantes entre as categorias etárias para homens e mulheres $(\mathrm{p}>0,05)$. O poder discriminante do volume dos seios pode suportar o planejamento de tratamento personalizado e específico do paciente com base no sexo.

Palavras-chave: Anatomia; Tomografia computadorizada do feixe de cone; Odontologia legal; Seio maxilar; Volume.

\section{Resumen}

Los estudios anatómicos encontraron en la tomografía computarizada de haz cónico (CBCT) un recurso óptimo para la evaluación tridimensional (3D) de la cabeza y el cuello. Cuando se trata de los senos maxilares, CBCT permite un análisis volumétrico confiable a tamaño real. Este estudio tuvo como objetivo evaluar los cambios relacionados con la edad y el sexo de los senos maxilares mediante el análisis volumétrico de CBCT. La muestra consistió en exploraciones CBCT de 112 individuos masculinos $(\mathrm{n}=57)$ y femeninos $(\mathrm{n}=55)$ (224 senos maxilares) distribuidos en 5 categorías de edad: $20|-30,31|-40,41|-50,51|-60$ y > 60 años. La adquisición de imágenes se realizó con el dispositivo i-CAT con un tamaño de vóxel de $0,25 \mathrm{~mm}$ y un campo de visión que incluía los senos maxilares (recolección retrospectiva de muestras de una base de datos existente). Se realizó la segmentación de imágenes se realizó en el software itk-SNAP. El volumen (mm3) de los senos segmentados se cuantificó y comparó por pares en función del lado (izquierda y derecha), el sexo (masculino y femenino) y la edad (cinco grupos). Las diferencias entre el volumen de los lados izquierdo y derecho no fueron estadísticamente significativas ( $p>0,05)$. El volumen medio de los senos maxilares en los hombres fue un $22 \%$ mayor que en las mujeres $(p=0,0001)$. Las diferencias volumétricas no fueron estadísticamente significativas entre las categorías de edad para hombres y mujeres $(p>0,05)$. El poder discriminante del volumen de los senos paranasales puede apoyar la planificación del tratamiento personalizada y específica del paciente basada en el sexo.
\end{abstract}

Palabras clave: Anatomía; Tomografía computarizada de haz cónico; Odontología forense; Seno maxilar; Volumen.

\title{
1. Introduction
}

The maxillary sinuses (MS) represent the larger pair of paranasal sinuses (Batista et al., 2011). As the other pairs, these anatomical structures are named after their surrounding bone. From the Latin language, the etymology of the MS originates from "antron", or in English "cavity" (Batista et al., 2011). Nathaniel Highmore was the responsible for the popularization of the eponym "Antrum of Highmore" in his early studies and descriptions of the bilateral pyramid-shaped cavity in the maxillae (Batista et al., 2011). The MS are the first paranasal sinuses to develop, starting in the 12th intrauterine week extending throughout the adolescence (Abubaker, 1999). In the first three years of life and between the 7-12th years the MS manifest a rapid growth (Cho et al., 2010). It is estimated that in the early adulthood (at the age of 18 years) the MS already have their mature anatomical aspect (Batista et al., 2011). Radiographically, the MS are visible from the 5th month of life (Abubaker, 1999). Their aspect is radiolucent and well-outlined by radiopaque bone limits (Ariji et al., 1994). The volume of the MS depends on biological aspects, such as age, sex and ancestry (Lee et al., 2009; Batista et al., 2011). Reported average volumetric values range around $14 \mathrm{~cm} 3$ (Ariji et al., 1994). Even with the end of the developmental process, the MS may express late changes in volume as the result of pneumatization (Kalavagunta \& Reddy, 2003), and loss of teeth and alveolar bone height (Sharan \& Madjar, 2008).

In the clinical practice, MS play an important part in surgical planning of implants, bone graft and dental extractions (McCarthy et al.; 2003; Kilic et al., 2010; Núñez-Márquez et al., 2021), among other procedures. The key position of these cavities in the viscerocranium reflects a close distance from the apices of maxillary teeth - making of them potential targets for a disseminated dental infection (Mendonça et al., 2021). More severe clinical involvement of the MS includes the maxillectomy and the excision of tumoral lesions (García et al., 2010). Understanding the potential anatomical differences of MS volume between patients of different age groups and sex, is essential to predict clinical intercurrences and improve technical performances. In parallel, the distinctive outline of the MS and the subsequent alleged variations based on age and sex have a valuable role in forensic sciences - especially when it comes to sexual dimorphism of victims (Won et al., 2010; 
Akhlaghi et al., 2017; Gomes et al., 2019) for human identification. The assessment of the MS into a 3D image segmentation scenario became available and subsequently more reliable with advanced tools that could import life-size volumes from cone beam computed tomography (CBCT) (12). Currently, CBCT consists of the state-of-the-art among imaging devices able to assess and quantify anatomical features of bony dental and maxillofacial structures.

This study aimed to assess the (late) age and sex-related changes of the MS volume using CBCT analysis and compatible segmentation tools for a 3D anatomical investigation.

\section{Methodology}

\section{Study design and ethical aspects}

An observational, analytical, cross-sectional study with retrospective sample collection was designed. The Strengthening the Reporting of Observational Studies in Epidemiology (STROBE) standards were followed (https://www.strobe-statement.org/checklists/) (Vandenbroucke et al., 2014). The study project was approved by the local committee of ethics in human research under the protocol number \#55687116.8.0000.0077.

\section{Participants and eligibility settings}

The sample consisted of CBCT scans of 112 individuals (57 males and 55 females) of Brazilian origin within an age interval between 20 and 85 years. The images registered 224 MS. All the images were collected retrospectively from an existing database and were previously obtained exclusively for diagnostic and treatment purposes. The imaging device used for image acquisition was the i-CAT Next Generation (Imaging Science International, Hatfield, PA, USA), considering field of views (FOV) that included the full volume of both the MS. Voxel size was $0.25 \mathrm{~mm}$.

The eligibility criteria consisted of including only CBCT files that had information about the date of image acquisition, individual date of birth and sex, and images that presented a full registration of the left and right MS. Low-quality CBCT images were excluded, as well as images from individuals younger than 18 years, images that presented sinus lesions or image artifacts over the MS, and images the presented maxillofacial orthopedic appliances in the maxilla or any sign of visual bone deformity.

\section{Variables}

The variables considered in the present study were the lateral position of the MS (left and right), the age of the sampled individuals, the sex, and the volume of the MS expressed in cubic millimeters (mm3). Specifically for the age, the continuous variable was converted into categorical ones by distributing the individuals into five age intervals: $20 \mid-30$ (n $=11$ males and 10 females), $31\lceil-40(\mathrm{n}=11$ males and 10 females $), 41 \mid-50(\mathrm{n}=14$ males and 13 females $), 51 \mid-60(\mathrm{n}=9$ males and 11 females) and $>60$ years $(n=12$ males and 11 females).

\section{Measurements}

The CBCT images in Digital Imaging and Communications in Medicine format were imported into itk-SNAP 3.8.0 software (www.itksnap.org) (Yushkevich et al., 2006) for 3D segmentation of the MS. A semi-automated technique was performed separately for each sinus. The first step consisted of locating the MS in multiplanar navigation (axial, sagittal and coronal planes). The second step was the pre-segmentation and consisted of setting the thresholding tools (between -500 and 1000 limits) to centralize and pre-determine the segmentation region. In the third step, the initialization takes part via bubble segmentation. In the multiplanar views, a bubble is positioned to automatically in the sinus space. Subsequently, the fourth step allows the evolution of the bubble into the MS - a process that may extrapolate the bone boundaries of the MS (Figure 1). 
External structures eventually included in the bubble will be manually "brushed" (brush tool) out before volume quantification (Figure 2). The fifth step is the image update to generate the segmented version of the MS. In the same individual, left and right segmented MS are distinguished through colour labeling (Figure 3). With the segmented images, the "volume and statistics" tool is used to quantify the data $(\mathrm{mm} 3)$. The combination of automated software inherent tools and manual brushing led to a semi-automated procedure.

Figure 1 - Axial (1), sagittal (2) and coronal (3) views of the maxillary sinuses during the identification (A), pre-segmentation (B), initialization (C) and evolution (D) steps during the semi-automated CBCT volume segmentation in itk-SNAP 3.8.0.

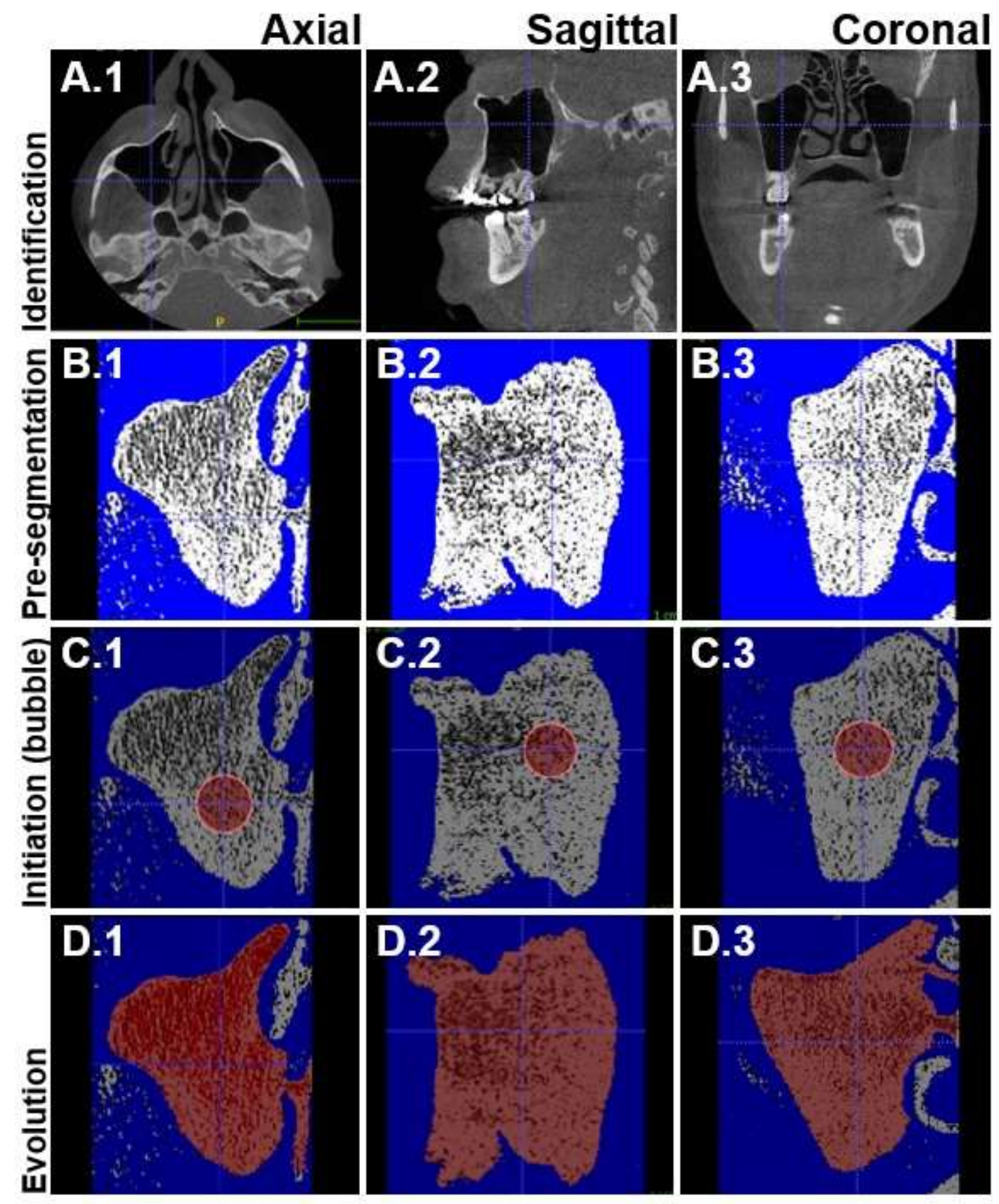

Source: Authors. 
Figure 2 - Manual component of the semi-automated volume segmentation in itk-SNAP software indicating (arrow) the "brushing" (exclusion) process of regions initially identified outside the bone boundaries of the maxillary sinus.

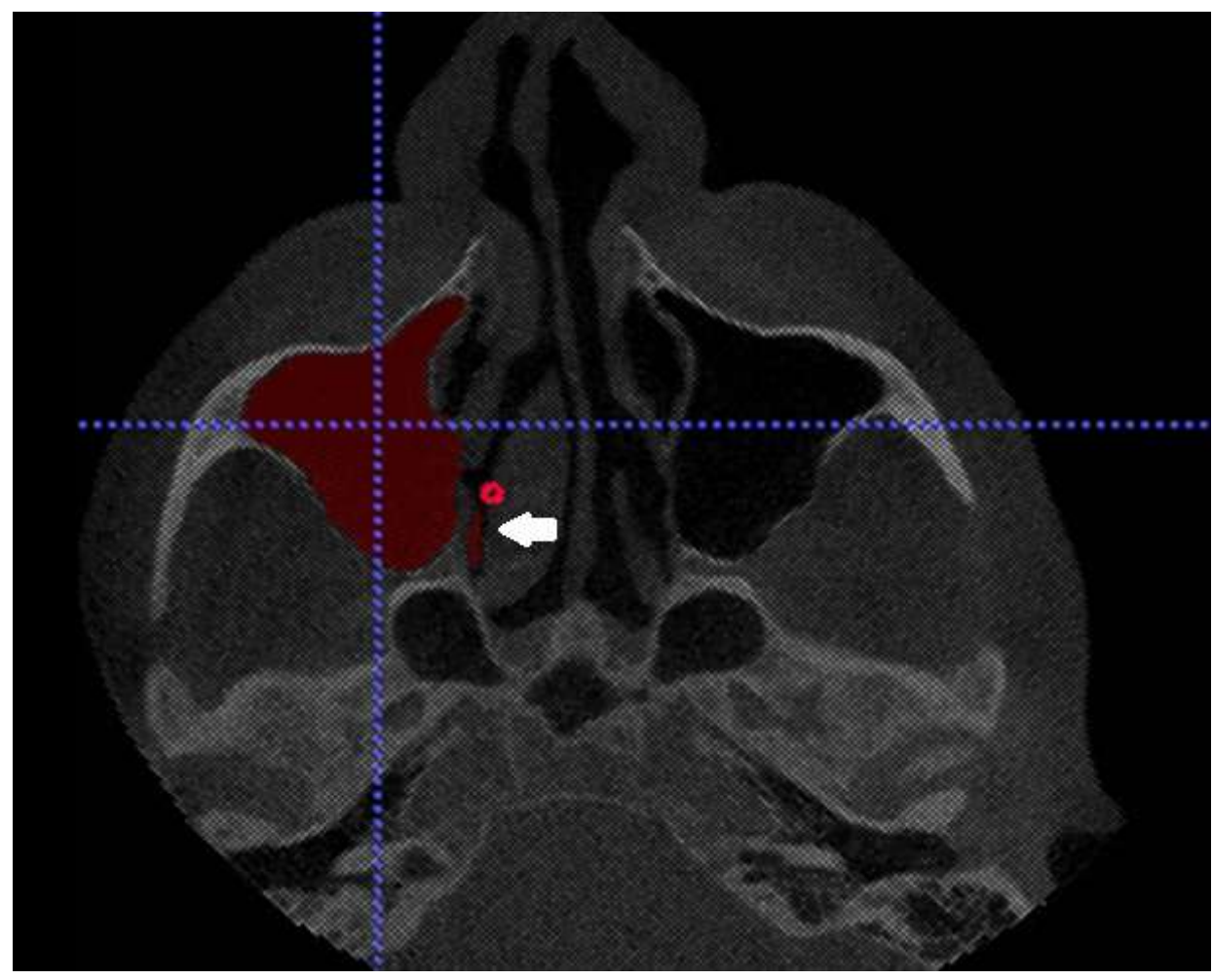

Source: Authors.

Figure 3 - Colour-labeled and segmented left and right maxillary sinuses of the same individual after the semi-automated process performed in itk-SNAP software. Both volumes were ready for volume calculation.

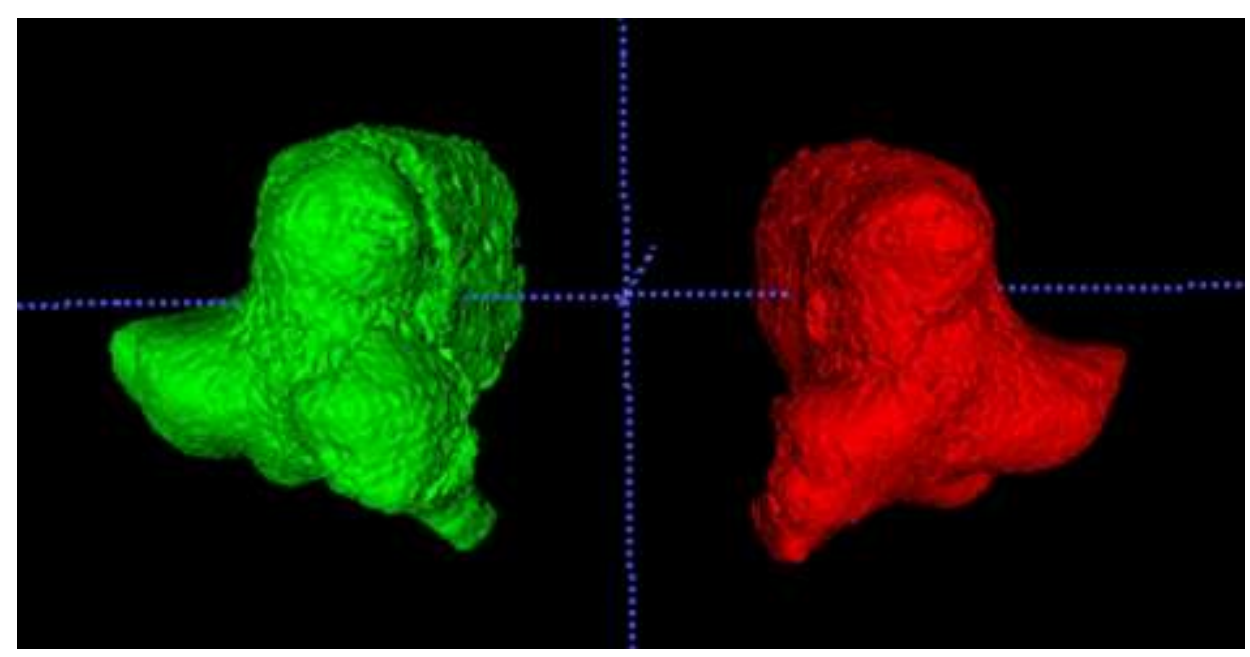

Source: Authors.

\section{Bias}

The operator-dependent procedures taken throughout the five steps previously describe in measurements were tested for their reproducibility. The main observer repeated $10 \%$ of the semi-automated segmentation steps and the calculation of volume outcomes within 30 days from the main (total sample) analysis. The quantified reproducibility was measured via Intraclass Correlation Coefficient (ICC). 


\section{Statistic methods}

Descriptive statistics of central tendency (means) and dispersion (standard deviation) were calculated. Absolute (n) and relative (\%) frequencies were used to present data. The normality of data distribution was assessed with Shapiro-Wilk test. Comparisons between the mean volumes of left and right sides were performed with paired t-test. Person's correlation coefficient was used to correlate volume of the MS with age groups. Anova (one-factor) and Tukey tests were used to compare MS volume between age groups for males and females. Statistical significance was set at $5 \%$ with a confidence interval of 95\%. SPSS software was used (IBM Corp., Armonk, USA).

\section{Results}

Observer reproducibility ranged between good 0.75-0.9, and excellent $>0.09$ (Koo et al., 2016).

Pairwise comparisons based on MS sides revealed a homogeneous similarity across age groups. The similarity rate ranged between $93.34 \%$ (detected in the age group of $51 \mid-60$ years) and $99.25 \%$ (detected in the age group of $20 \mid-30$ years). The mean difference between left and right MS volume was $3.12 \pm 2.22 \%$. P-values for all the age groups were $>0.05$ (Table 1).

Table 1 - Volumetric differences between left and right maxillary sinuses for each of the studied age categories.

\begin{tabular}{|c|c|c|c|c|c|}
\hline Sex & Age & $\mathbf{n}$ & Mean & SD & $p$ \\
\hline \multirow[t]{10}{*}{ M } & $20-30 \mathrm{R}$ & 11 & 17713,40 & 6176,70 & 0.724 \\
\hline & $20-30 \mathrm{~L}$ & 11 & 19569,10 & 4461,50 & \\
\hline & $31-40 \mathrm{R}$ & 11 & 14793,60 & 4859,30 & 0.814 \\
\hline & $31-40 \mathrm{~L}$ & 11 & 14327,20 & 4476,60 & \\
\hline & $41-50 \mathrm{R}$ & 14 & 16201,80 & 5559,60 & 0.477 \\
\hline & $41-50 \mathrm{~L}$ & 14 & 16679,00 & 5183,30 & \\
\hline & $51-60 R$ & 9 & 16186,70 & 4254,70 & 0.117 \\
\hline & $51-60 \mathrm{~L}$ & 9 & 16690,00 & 3876,50 & \\
\hline & $>61 R$ & 12 & 17263,70 & 4306,70 & 0.265 \\
\hline & $>61 \mathrm{E}$ & 12 & 18529,20 & 4151,20 & \\
\hline \multirow[t]{10}{*}{$\mathrm{F}$} & $20-30 \mathrm{R}$ & 10 & 12670,10 & 2954,70 & 0.079 \\
\hline & $20-30 \mathrm{~L}$ & 10 & 12921,70 & 3881,40 & \\
\hline & $31-40 \mathrm{R}$ & 10 & 11752,30 & 2741,40 & 0.670 \\
\hline & $31-40 \mathrm{~L}$ & 10 & 11665,30 & 3540,90 & \\
\hline & $41-50 \mathrm{R}$ & 13 & 12959,00 & 3425,10 & 0.630 \\
\hline & $41-50 \mathrm{~L}$ & 13 & 13335,20 & 3951,70 & \\
\hline & $51-60 R$ & 11 & 14522,70 & 6316,10 & 0.666 \\
\hline & $51-60 \mathrm{~L}$ & 11 & 13556,70 & 5475,80 & \\
\hline & $>61 R$ & 11 & 13451,50 & 4370,50 & 0.095 \\
\hline & $>61 \mathrm{~L}$ & 11 & 13937,70 & 4766,80 & \\
\hline
\end{tabular}

Mean values expressed in $\mathrm{mm}^{3}$; age values expressed in years. M: male; F: female; R: right; L: left; SD standard deviation; statistical significance set at $5 \%(p)$. Source: Authors. 
Comparisons between the volumetric anatomy of the MS in males and females revealed statistically significant differences. The overall mean volume of males $\left(16.8080 \pm 4.869 \mathrm{~mm}^{3}\right)$ was $22 \%$ higher than the mean female volume $(13.110$ $\left.\pm 4.192 \mathrm{~mm}^{3}\right)(\mathrm{p}=0.0001)$. The higher values for male MS volume was constant throughout the age categories. Volume (male $>$ female) volume discrepancy reached $31.35 \%, 19.58 \%, 20.03 \%, 14.58 \%$ and $23.47 \%$ in the age categories $20|-30,31|-$ $40,41|50,51| 60$ and > 60 years, respectively. The larger mean MS volume detected in the sample (18.641 \pm 5.343 $\mathrm{mm}^{3}$ ) was found in males of the age category $20 \mid-30$ years, while the smallest mean volume $\left(11.709 \pm 3082 \mathrm{~mm}^{3}\right) \mathrm{was}^{-}$ reported in females of the age category $31 \mid-40$ years (Table 2 ).

Table 2 - Volumetric differences between male and female maxillary sinuses for each of the studied age categories.

\begin{tabular}{|c|c|c|c|c|c|c|c|c|c|c|}
\hline Age & \multicolumn{2}{|c|}{$20-30$} & \multicolumn{2}{|c|}{$31-40$} & \multicolumn{2}{|c|}{$41-50$} & \multicolumn{2}{|c|}{$51-60$} & \multicolumn{2}{|c|}{$>60$} \\
\hline Sex & $\mathbf{F}$ & $\mathbf{M}$ & $\mathbf{F}$ & $\mathbf{M}$ & $\mathbf{F}$ & $\mathbf{M}$ & $\mathbf{F}$ & $\mathbf{M}$ & $\mathbf{F}$ & $\mathbf{M}$ \\
\hline $\mathrm{n}$ & 20 & 22 & 20 & 22 & 26 & 28 & 22 & 18 & 22 & 24 \\
\hline Mean & 12796 & 18641 & 11709 & 14560 & 13147 & 16440 & 14040 & 16438 & 13695 & 17896 \\
\hline $\mathrm{SD}$ & 3360 & 5343 & 3082 & 4566 & 3628 & 5280 & 5790 & 3957 & 4470 & 4187 \\
\hline$p$ & \multicolumn{2}{|c|}{0.00} & \multicolumn{2}{|c|}{0.02} & \multicolumn{2}{|c|}{0.01} & \multicolumn{2}{|c|}{0.14} & \multicolumn{2}{|c|}{0.00} \\
\hline
\end{tabular}

$\mathrm{n}$ : sampled maxillary sinuses; SD: standard deviation: F: females; M: males; age expressed in years and volume expressed in $\mathrm{mm}^{3}$; statistical significance set at 5\% ( $\left.p\right)$. Source: Authors.

The age-associations between mean volumetric values of the MS regardless of sex were not statistically significant for each of the studies age categories ( $p>0.05$ ). In males, the mean volume of the MS decreased from the age category $20 \mid-30$ to $31-40$ about $22 \%$. A subsequent volume increase of $11 \%$ was observed into age category $41 \mid 50$, maintaining in the age category of $51 \mid-60$. Entering the final age category (>60 years), an increase of $8 \%$ was observed. In females, the initial MS volume in age category $20-30$ decreased $8,5 \%$ to the category $31-40$, increasing $10 \%$ and $6 \%$ in the two next age categories. Into the final category ( $>60$ years), a volume decrease of 2,45\% was observed. Age-related changes in volume were more significant in males, but there was no evident increase / decrease pattern of the MS volume with age in the adulthood (after the age of 20 years; $p$ > 0.05) (Table 3).

Table 3 - Associations of mean volumetric values of the maxillary sinuses across each of the studied age categories.

\begin{tabular}{|c|c|c|c|c|c|}
\hline Males & $20-30(n=22)$ & $31-40(n=22)$ & $41-50(n=28)$ & $51-60(n=18)$ & $>60(n=24)$ \\
\hline $20-30$ & $18641(5343)^{*}$ & $0.01 * *$ & $0.15^{* *}$ & $0.15^{* *}$ & $0.60 * *$ \\
\hline $31-40$ & $0.01 * *$ & $14560(4566)^{*}$ & $0.19 * *$ & $0.18 * *$ & $0.13 * *$ \\
\hline $41-50$ & $0.15^{* *}$ & $0.19 * *$ & $16440(5280)^{*}$ & $0.99 * *$ & $0.28 * *$ \\
\hline $51-60$ & $0.15^{* *}$ & $0.18 * *$ & $0.99 * *$ & $16438(3957)^{*}$ & $0.26 * *$ \\
\hline$>60$ & $0.60 * *$ & $0.13 * *$ & $0.28 * *$ & $0.26 * *$ & $17896(4187)^{*}$ \\
\hline Females & $20-30(n=20)$ & $31-40(n=20)$ & $41-50(n=26)$ & $51-60(n=22)$ & $>60(n=22)$ \\
\hline $20-30$ & $12796(3360)^{*}$ & $0.29 * *$ & $074 * *$ & $0.40 * *$ & $0.46^{* *}$ \\
\hline $31-40$ & $0.29 * *$ & $11709(3082)^{*}$ & $0.16^{* *}$ & $0.12 * *$ & $0.10 * *$ \\
\hline $41-50$ & $0.74 * *$ & $0.16^{* *}$ & $13147(3628)^{*}$ & $0.52 * *$ & $0.64 * *$ \\
\hline 51-60 & $0.40 * *$ & $0.12 * *$ & $0.52^{* *}$ & $14040(5790)^{*}$ & $0.83^{* *}$ \\
\hline$>60$ & $0.46^{* *}$ & $0.10 * *$ & $0.64 * *$ & $0.83^{* *}$ & $13695(4470)^{*}$ \\
\hline
\end{tabular}

*Mean volume representing the MS of each age category (and respective standard deviations); **p-value for the tested association between the age categories. Statistical significance set at 5\%. Equal letters indicate lack of statistical significance $(\mathrm{p}>0.05)$ and distinct letters indicate statistically significant differences $(\mathrm{p}<0.05)$. Source: Authors. 


\section{Discussion}

Surgical intercurrences in dentistry may manifest as accidents or complications. The former consists of undesired intraoperative events (predictable or not), while the latter is a postoperative (Silva et al., 2017). Examples of accidents that involve the MS are the oroantral communication (Polat et al., 2007) and the displacement of foreign bodies into the sinus (Toledano-Serrabona et al., 2021). In these cases, nose bleeding and sinusitis may emerge as complications (Chang et al., 2020). Large (high-volume) MS with thin walls are more prone to wall fracture and oroantral communication (Polat et al., 2007). Dental extractions are ranked on the top litigations against dentists (BDJ Upfront, 2019). Reviewing 20 cases of malpractice, Marei (2003) found out that most of the lawsuits were against general dentists doing single extractions of maxillary teeth. Moreover, according ot the author, the most common cause of clinical claims was the "regurgitation of fluid through the nose due to oro-antral communication following tooth extraction" (Marei, 2003). Planning surgical procedures with advanced imaging, such as CBCT seems to be a proper protective conduct to safeguard patient's health. The present study finds in this scenario the utmost justification for the study of MS volume.

The first main finding of this study was the symmetrical anatomy of the MS between left and right sides (>93\% of volumetric similarity). This outcome illustrates the anatomical theory of antimers - that emerge from the median division of the human body into two mirrored parts. Similar outcomes were observed in previous studies that investigated the MS with metric and volumetric (segmentation) tools (Przystańska et al., 2018; Gomes et al., 2019), and exclusively metric (linear) tools (Przystańska et al., 2018). The comparison of the present study findings and the existing literature (Gomes et al., 2019, Przystańska et al., 2018) suggests that the bilateral similarity of the MS do not occur by chance and that it is not techniquedependent (since it manifests by means of linear measurements and volumetric segmentation.

When it comes to sex-related changes of the MS, this study showed statistically significant differences $(p=0.0001)$ between males and females. More specifically, the volume of male MS was constantly higher than females across age categories and also regardless the age (combining all categories). In average, the mean volume of male MS was $22 \%$ higher than the female volume - reaching a volume higher up to $31.35 \%$ in the age category of $20 \mid-30$ years. The sexual dimorphism of the MS volume has been proved in different populations, namely the Brazilian (Gomes et al., 2019), Polish (Przystańska et al., 2018), Peruvian (Bezada-Carrasco et al., 2021), Korean (Jun et al., 2005) among others. Interestingly, comparing linear measurements of height, width and depth (anteroposterior) with volumetric data, authors (Przystańska et al., 2020) were able to observed sexual dimorphism even in children (which do not manifest sexual differences easily before pubertal expression). According to the authors, the volume of the MS figured as the most dimorphic variable (Przystańska et al., 2020). Differently, Gomes et al. (2019) and Bezada-Carrasco et al. (2021) found the MS height as the most dimorphic feature in samples of the Brazilian and Peruvian populations. Specifically, the MS height was able to correctly distinguish $77.7 \%$ of the individuals sampled in the study of Gomes et al. (2019). Less promising accuracy rates down to $67 \%$ (Sharma et al., 2014) and 71\% (Urooge \& Patil, 2017) were reported in the scientific literature. Understanding that the volumetric analysis could enable a more comprehensive assessment of the full anatomy of the MS, the present study decided for exclusive volumetric quantification. Among the advantages of the volumetric analysis, also performed by Gomes et al. (2019), is the possibility of including computer-guided decisions for a semi-automated process during the segmentation steps - which could reduce the operator-dependent bias.

MS development extends throughout the childhood and adolescence. During this period age-related anatomical changes are normally expected (Przystańska et al., 2018; Przystańska et al., 2020). The present study sampled individuals older than 18 in order to screen eventual anatomical changes in volume in the adulthood. Clearly, any detected volumetric change would not result from development or residual growth, but possibly from pneumatization. Despite the lack of statistically significant changes influenced by age, it was possible to observe volumetric alterations (increase and decrease) across the age 
categories that were more evident in males. This is to say that adult females may manifest MS volumetric changes more discretely than males. Early studies performed by Ariji et al. (1994) claimed a decrease in MS volume after the age of 20. In the present study, mean volumetric values floated between age categories. The difference between studies may be explained firstly by the weak correlation coefficient (-0.43) presented in the early studies of Ariji et al. (1994) that could indicate an inconsistent volumetric decrease. Secondly, the present study stratified the sample into five age categories - a methodological decision that could enable a more detailed assessment of the age-related changes in MS volume. Hence, the present study benefits from previous literature to attempt methodological improvements to reach contemporary and reliable results.

Future studies in the field should be designed to propose and test fully automated processing that could include artificial intelligence into the selection of MS as the region of interest. Accordingly, computerized segmentation with minimum post-processing cleaning of the selection region of interest could enhance future studies.

\section{Conclusion}

The volumetric assessment of MS anatomy revealed high similarity between left and right sides. Sex-related changes in anatomy significantly altered the MS volume. The overall mean volume of the MS in males was $22 \%$ higher than the mean volume in females. Age-related anatomical changes in the adulthood more evident in males, but not consistent across the five studies age categories.

\section{References}

Abubaker, A. O. (1999). Applied anatomy of maxillary sinus. Oral Maxillofac Surg Clin North Am, 11, 1-13.

Akhlaghi, M., Bakhtavar, K., Kamali, A., Maarefdoost, J., Sheikhazadi, A., Mousavi, F. et al. (2017). The diagnostic value of anthropometric indices of maxillary sinuses for sex determination using CT-scan images in Iranian adults: A cross-sectional study. J Forensic Leg Med, 49, 94-100. https://doi.org/10.1016/j.jflm.2017.05.017

Ariji, Y., Kuroki, T., Moriguchi, S., Ariji, E. \& Kanda, S. (1994). Age changes in the volume of the human maxillary sinus: A study using computed tomography. Dentomaxillofac Radiol, 23, 163-168.

Batista, P. S., Franco, A. \& Wichnieski, C. A. (2011). Contribution to the maxillary sinus study. Rev Port Estomatol Med Dental Cir Maxillofac, 52(4), 235239. https://doi.org/10.1016/j.rpemd.2011.04.003

Bezada-Carrasco, R., Suárez-Ponce, D. G., Alvitez-Temoche, D., Ayala, G., Watanabe, R., Salcedo-Moncada, D. et al. (2021). Forensic evaluation of Highmore antrum sexual dimorphism by cone beam computed tomography: a retrospective study of a Peruvian population. J Int Soc Prev Community Dent, 11(1), 13-18. https://doi.org/https://doi.org/10.4103/jispcd.jispcd_315_20

British Dental Journal Upfront section. (2019). Extractions are main cause of patients' dental claims. Br Dent J, 226, 480. https://doi.org/10.1038/s41415-0190222-X

Chang, P. H., Chen, Y. W., Huang, C. C., Fu, C. H., Huang, C. C. \& Lee, T. J. (2020). Removal of displaced dental implants in the maxillary sinus using endoscopic approaches. Ear Nose Throat J, 145561320931304. https://doi.org/10.1177/0145561320931304

Cho, S. H., Kim, T. H., Kim, K. R., Lee, J. M., Lee, D. K., Kim, J. H., et al. (2010). Factors for maxillary sinus volume and craniofacial anatomical features in adults with chronic rhinosinusitis. Arch Otolaryngol Head Neck Surg, 136(6), 610-615. https://doi.org/10.1001/archoto.2010.75

García, B., Peñarrocha, M., Peñarrocha, M. A. \& Von Arx, T. (2010). Apical surgery of a maxillary molar creating a maxillary sinus window using ultrasonics: a clinical case. Int Endod J, 43, 1054-1061. https://doi.org/10.1111/j.1365-2591.2010.01776.x

Gomes, A. F., Gamba, T. O., Yamasaki, M. C., Groppo, F. C., Haiter-Neto, F. \& Possobon, R. F. (2019). Development and validation of a formula based on maxillary sinus measurements as a tool for sex estimation: a cone beam computed tomography study. Int J Legal Med, 133(4), 1241-1249. https://doi.org/10.1007/s00414-018-1869-6

Jun, B. C., Song, S. W., Park, C. S., Lee, D. H., Cho, K. J. \& Cho, J. H. (2005). The analysis of maxillary sinus aeration according to aging process, volume assessment by 3-dimensional reconstruction by high resolution CT scanning. Otolaryngol Head Neck Surg, 132, 429-434. https://doi.org/10.1016/j.otohns.2004.11.012

Kalavagunta, S. \& Reddy, K. T. (2003). Extensive maxillary sinus pneumatization. Rhinology, 41(2), 113-117.

Kilic, C., Kamburoglu, K., Yuksel, S. P. \& Ozen, T. (2010). An assessment of the relationship between the maxillary sinus floor and the maxillary posterior teeth root tips using dental cone-beam computerized tomography. Eur J Dent, 4, 462-467. http://dx.doi.org/10.1055/s-0039-1697866 
Koo, T. K. \& Li, M. Y. (2016). A Guideline of selecting and reporting intraclass correlation coefficients for reliability research. J Chiropr Med, 15(2), 155163. https://dx.doi.org/10.1016\%2Fj.jcm.2016.02.012

Lee, F. C., Fernandes, C. M. C. \& Murrell, H. C. (2009). Classification of the maxillary sinus according to area of the medial antral wall: a comparison of two ethnic groups. J Oral Maxillofac Surg, 2009, 8(2), 103-107. https://doi.org/10.1007/s12663-009-0027-6

Marei, H. F. (2013). Medical litigation in oral surgery practice: Lessons learned from 20 lawsuits. J Forensic Legal Med, 20(4), 223-225. https://doi.org/10.1016/j.jflm.2012.09.025

McCarthy, C., Patel, R. R., Wragg, P. F. \& Brook, I. M. (2003). Sinus augmentation bone grafts for the provision of dental implants: report of clinical outcome. Int J Oral Maxillofac Implants, 18(3), 377-382.

Mendonça, D. S., Kurita, L. M., Carvalho, F. S. R., Tuji, F. M., Silva, P. G. B., Bezerra, T. P. et al. (2021). Development and validation of a new formula for sex estimation based on multislice computed tomographic measurements of maxillary and frontal sinuses among Brazilian adults. Dentomaxillofac Radiol, 50(6), 20200490. https://doi.org/10.1259/dmfr.20200490

Núñez-Márquez, E., Salgado-Peralvo, A. O. \& Peña-Cardelles, J. F. (2021). Removal of a migrated dental implant from a maxillary sinus through an intraoral approach: A case report. J Clin Exp Dent, 13(7), e733-6. https://doi.org/10.4317\%2Fjced.58350

Polat, H. B., Ay, S. \& Kara, M. I. (2007). Maxillary tuberosity fracture associated with first molar extraction: a case report. Eur J Dent, 1(4), $256-259$.

Przystańska, A., Kulczyk, T., Rewekant, A., Sroka, A., Jończyk-Potoczna, K., Lorkiewicz-Muszyńska, D. et al. (2018). Introducing a simple method of maxillary sinus volume assessment based on linear dimensions. Ann Anat, 215, 47-51. https://doi.org/10.1016/j.aanat.2017.09.010

Przystańska, A., Rewekant, A., Sroka, A., Gedrange, T., Ekkert, M., Jończyk-Potoczna, K. et al. (2020). Sexual dimorphism of maxillary sinuses in children and adolescents - A retrospective CT study. Ann Anat, 229, 151437. https://doi.org/10.1016/j.aanat.2019.151437

Sharan, A. \& Madjar, D. (2008). Maxillary sinus pneumatization following extractions: a radiographic study. Int J Oral Maxillofac Implants, 23(1), 48-56. https://doi.org/10.7759/cureus.6611

Sharma, S. K., Jehan, M. \& Kumar, A. (2014). Measurements of maxillary sinus volume and dimensions by computed tomography scan for gender determination. J Anat Soc Ind, 63(1), 36-42. https://doi.org/10.1016/j.jasi.2014.04.007

Silva, W. S., Silveira, R. J., Andrade, M. G. B. A., Franco, A., Silva, R. F. (2017). Is the late mandibular fracture from third molar extraction a risk towards malpractice? Case report with the analysis of ethical and legal aspects. J Oral Maxillofac Res, 8(2), e5. https://doi.org/10.5037/jomr.2017.8205

Toledano-Serrabona, J., Cascos-Romero, J. \& Gay-Escoda, C. (2021). Accidental dental displacement into the maxillary sinus during extraction maneuvers: a case series. Med Oral Patol Oral Cir Bucal, 26(1), e102-107. https://doi.org/10.4317/medoral.24054

Urooge, A. \& Patil, B. A. (2017). Sexual dimorphism of maxillary sinus: a morphometric analysis using cone beam computed tomography. J Clin Diag Res, 11(3), ZC67-70. https://doi.org/10.7860/jcdr/2017/25159.9584

Vandenbroucke, J. P., Von Elm, E., Altman, D. G., Gøtzsche, P. C., Mulrow, C. D., Pocock, S. J. et al. (2014). Strengthening the Reporting of Observational Studies in Epidemiology (STROBE): explanation and elaboration. Int J Surg, 12(12), 1500-1524. https://doi.org/10.1016/j.ijsu.2014.07.014

Won, H. S., Chun, S. H., Kim, B. S., Chung, S. R., Yoo, I. R., Jung, C. K. et al. (2009). Treatment outcome of maxillary sinus cancer. Rare Tumors, 1(2), e36. https://doi.org/10.4081\%2Frt.2009.e36

Yushkevich, P. A., Piven, J., Hazlett, H. C., Smith, R. G., Ho, S., Gee, J. C. et al. (2006). User-guided 3D active contour segmentation of anatomical structures: Significantly improved efficiency and reliability. Neuroimage, 31(3), 1116-1128. https://doi.org/10.1016/j.neuroimage.2006.01.015 